\title{
Research on technology clusters and the energy efficiency of energy-saving retrofits of existing office buildings in different climatic regions
}

\author{
Qibo Liu* (1) and Juan Ren
}

\begin{abstract}
Background: During the period of the "12th Five-Year Plan," energy demand exhibited a rigorous growth trend along with the acceleration of industrialization and urbanization and the constant upgrading of consumption structure. Therefore, the path that all cities and provinces must take towards sustainable development required by the "13th Five-Year Plan" is to enhance research on the energy efficiency of buildings, especially existing buildings; sufficiently evaluate regional building energy demands and the characteristics of resources and environment; and formulate regional technical measures and policies for building practical energy efficiency measures.

Methods: In this research, building energy-saving technologies are classified into four categories, i.e., green energy efficiency technologies for building envelopes, renewable energy sources, HVAC equipment systems, and architectural environment control systems. The existing office buildings representing different architectural climatic regions (cold region A, cold region B, and hot-summer cold-winter region) under the jurisdiction of Shaanxi province, China, are selected as the objects of research to discuss "typical buildings" in-depth.

Results and conclusions: The research finds that even for buildings of the same type, the energy efficiency retrofit technologies selected for them are quite different because the buildings are situated in different climatic regions. For example, in regard to the materials, such as low-E hollow glass doors and windows, high transparency materials should be selected for cold regions, whereas sun-shading materials should be selected for hot-summer cold-winter regions. In comparison with the Standard for Energy Consumption of Civil Buildings (GB/T 51161-2016), the energy consumption of the existing office buildings that have been retrofitted can basically reach the threshold values specified by the national standard, but there is still a distance from the guideline values, which is related to the technology clusters selected and the economic category and can be corrected in practical applications. This research establishes technology cluster systems for energy efficiency retrofits that are suitable for different climatic regions. This work also assists relevant departments in formulating the local energy use quotas for existing public buildings, promotes the management of energy efficiency by local governments for public buildings, and provides theoretical and technical support for the low-carbon ecological development of Chinese cities.
\end{abstract}

Keywords: Different climate regions, Office building, Energy efficiency, Technology cluster, Energy-saving retrofit

\footnotetext{
*Correspondence: linka_0@163.com

Department of Architecture, Chang'an University, Xi'an 710061, China
} 


\section{Background}

According to the statistics of the Report on the Development of Building Energy Efficiency in China 2016 issued by the Promotion Center for Science and Technology Development under the Ministry of Housing and UrbanRural Development of China [1], the energy consumption of civil buildings (including public and residential buildings) in China increased from 644 million tce to 797 million tce (for Chinese standard, 1 tce $=2.93 \mathrm{GJ}$ ) from 2009 to 2013, a nearly 1.24-fold increase accounting for $19.6 \%$ of the total final energy consumption of the whole society.

Rapid urbanization in China has given rise to significant increases in public building area (in China, buildings are categorized into industrial and civil buildings, and civil buildings are divided into public and residential buildings) [2]. Since 2001, the completed area of public buildings has reached 6 billion $\mathrm{m}^{2}$ and accounts for $60 \%$ of the current public building inventory, meaning that more than half of public buildings were built after 2001 . The public building area per capita in urban areas of China rapidly rose from $9 \mathrm{~m}^{2}$ in 2001 to $14 \mathrm{~m}^{2}$ in 2013 (only counting the urban population), close to the level of developed Asian countries such as Japan and Singapore.

The high energy consumption problem of public buildings, especially large ones, has become increasingly prominent [3]. The power consumption of government agencies' office buildings and large public buildings accounts for $22 \%$ of the total urban power consumption of China (including all power consumption as industrial and civil electricity consumption in urban areas) [4]. The power consumption per square meter of such buildings is 10-20 times that of ordinary residential buildings and 1.5-2 times that of similar buildings in developed countries, and furthermore, this trend exhibits strong growth. The primary causes of the high energy consumption of public buildings should be analyzed from two perspectives, namely, design and operation [5]. From the perspective of the design stage, the phenomenon of "the output power of the electric supply equipment is large, but the load is small" exists in most public buildings, leading to a great difference between design and actual conditions. It can be seen from the statistical data of the Report on the Development of Building Energy Efficiency in China 2014 that there were large differences in the energy consumption of public buildings in different architectural climatic regions (the figure mainly shows the difference between different climatic regions, and high energy consumption would be influenced by poor operational management) [6]. Take the energy consumption (except that of municipal central heating, which means municipal central heating in North China, which usually uses natural gas) of civil buildings in different climatic regions, for example, as shown in Fig. 1. Through comparison of the energy consumption intensities (except that of municipal central heating) of various civil buildings in four architectural climatic regions in the figure, it is shown on the whole that the energy consumption of various public buildings in hot-summer cold-winter and hot-summer warm-winter regions is higher than those in severe cold and cold regions, which is because of the difference in the frequency of air conditioning use. With respect to the large public buildings in the figure, the energy consumption intensity (except that of municipal central heating) in hot-summer warm-winter regions is basically equivalent to that in hot-summer cold-winter regions, while the energy consumption intensity in the severe cold region is approximately three fourths of that in other climatic regions. The primary causes of the high energy consumption of public buildings should be analyzed from two perspectives, namely, design and operation. From the perspective of the design stage, the output power of the electric supply equipment is large, but the load is small in most public buildings, leading to a great difference between the design and actual conditions.

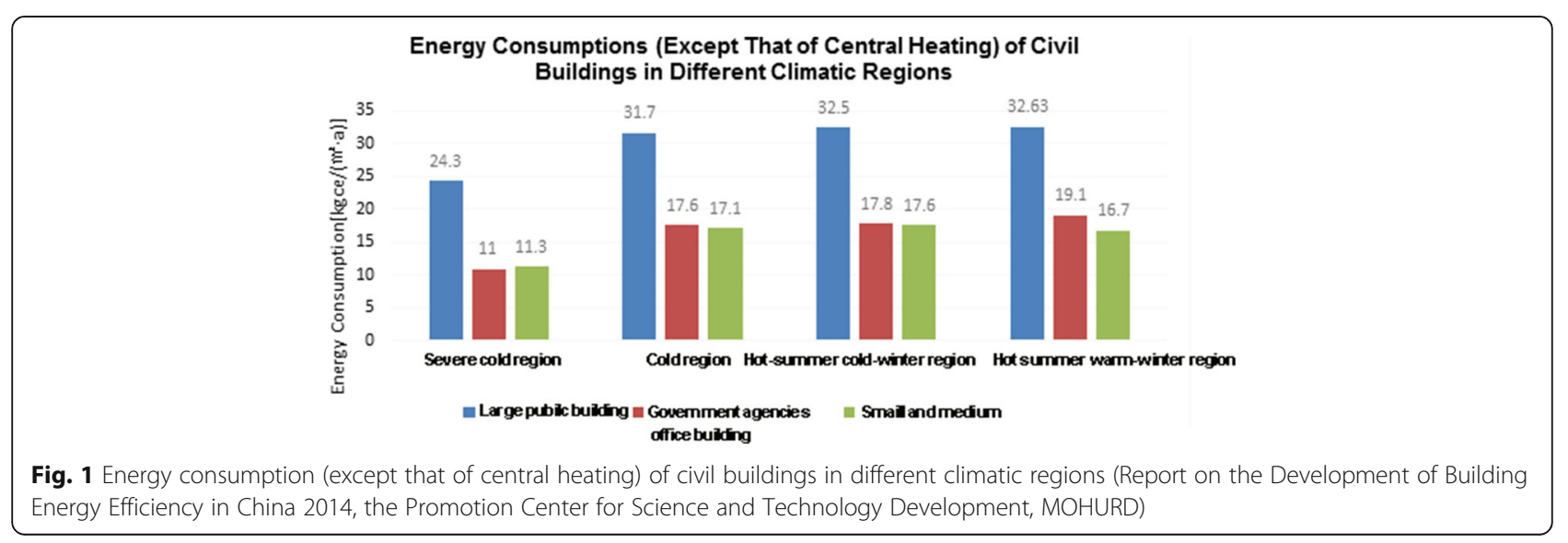




\section{Methods}

In this research, we classify building energy-saving technologies into four categories, i.e., green energy efficiency technologies for building envelopes, renewable energy sources, HVAC equipment systems, and architectural environment control systems; on the basis of effective classification, evaluation, and analyses of the energy efficiency technologies for public buildings, a systematic and complete list of technologies is formed, and technology cluster systems are established for energy efficiency retrofits suitable for different climatic regions. Within the scope of different architectural climatic regions (cold region $\mathrm{A}$, cold region $\mathrm{B}$, and hotsummer cold-winter region, shown in Table 1) under the jurisdiction of Shaanxi province, China, the research selects representative existing office buildings for analysis. This work first carries out an in-depth survey to establish climatic feature-based technology clusters for the energy efficiency retrofit of existing office buildings. Then, "typical buildings" are discussed in an in-depth manner, as are the energy efficiency technology clusters in an integrated scheme, high-cost-performance scheme, and economical scheme. These factors are imported into a building model for simulations in order to conduct in-depth analyses of the energy efficiencies due to retrofitting with different building energy efficiency technologies. Finally, the results are used to assist the relevant departments in establishing the energy use quotas of the office buildings in different regions and provide bases for the formulation of local regulations and policies on energy efficiency.

\section{Analysis of the energy consumption of existing office buildings in different climatic regions}

At present, the energy consumption of office buildings in Shaanxi province mainly includes electric energy, natural gas, and municipal heating in winter, among which electric energy is dominant. Currently, there is a lack of accurate measurements of natural gas consumption and municipal heating capacity, so electric energy, the main type of energy consumption, is taken as the major research object.

The survey of the Shaanxi Research Institute of Building Sciences on the energy consumption of 10 governmental office buildings of Shaanxi reflects indicators of the actual energy consumption level and energy efficiency potential of Shaanxi governmental office buildings (the 10 governmental office buildings are selected as typical buildings for the research) [7]. The survey covers governmental office buildings in Xi'an, Yan'an, Baoji, Yulin, and Hanzhong, and the scope is of relatively good representativeness.

The survey finds that the calculated heat consumption and coal consumption of the selected governmental office buildings are $28.5-52.5 \mathrm{~W} / \mathrm{m}^{2}$ and $21.6-34.5 \mathrm{~kg} / \mathrm{m}^{2}$, respectively. The lighting of office buildings uses fluorescent lamps in most cases; the air conditioners in many office buildings are independent and split, and the use of air conditioners varies greatly with the architectural climatic region. The annual power consumption of the selected office buildings is below $40 \mathrm{~kW} / \mathrm{m}^{2}$, and 760 old-fashioned four-column cast-iron radiators are mainly adopted as the heating system, but its heat dissipation effect is unsatisfactory due to the small dissipation area of a single fin. Because the majority of governmental office buildings were built in the 1980s, there have been few incandescent lamps and three-band fluorescent lamps are used. Voice- and light-operated switches and time-delay switches are widely used. The survey finds that the power consumption of air conditioners in Shaanxi governmental office buildings is relatively high, followed by that of building lighting, and the power consumption of other electric appliances is comparatively low (Fig. 2).

According to the field survey, more than $50 \%$ of the existing office buildings in Shaanxi were built prior to 2005, when China had not issued the corresponding specification to restrict building energy consumption [8]. Hence, the buildings completed prior to 2005 are mostly highly energy-consuming. In the wake of the popularization of air conditioners and heating equipment, these buildings have no choice but to exchange the high energy consumption of external equipment for indoor thermal comfort for the purpose of improving indoor thermal comfort conditions as bad thermal conditions would require the operation of equipment to reach a comfortable temperature. Such buildings also have the greatest potential for energy efficiency retrofits and influence today's society greatly because of the large number of such buildings and their high energy consumption. This research selects typical office buildings in Yulin city in cold region A, Xi'an city in cold region $\mathrm{B}$, and Hanzhong city in hot-summer cold-winter region as the survey objects, and the

Table 1 The climate conditions of selected typical cities (self-drawn)

\begin{tabular}{|c|c|c|c|c|c|}
\hline $\begin{array}{l}\text { Architectural climatic } \\
\text { region }\end{array}$ & Typical city & $\begin{array}{l}\text { The hottest month average } \\
\text { temperature (July) }\left({ }^{\circ} \mathrm{C}\right)\end{array}$ & $\begin{array}{l}\text { The coldest month average } \\
\text { temperature (January) }\left({ }^{\circ} \mathrm{C}\right)\end{array}$ & $\begin{array}{l}\text { Extreme maximum } \\
\text { temperature (July) }\left({ }^{\circ} \mathrm{C}\right)\end{array}$ & $\begin{array}{l}\text { Extreme minimum } \\
\text { temperature (January) }\left({ }^{\circ} \mathrm{C}\right)\end{array}$ \\
\hline Cold region $\mathrm{A}$ & Yulin & 23.3 & -9.4 & 38.6 & -30 \\
\hline Cold region $B$ & Xi'an & 26.6 & -0.1 & 40.3 & -16 \\
\hline $\begin{array}{l}\text { Hot-summer and } \\
\text { cold-winter }\end{array}$ & Hanzhong & 25.2 & 2.4 & 38.3 & -7 \\
\hline
\end{tabular}




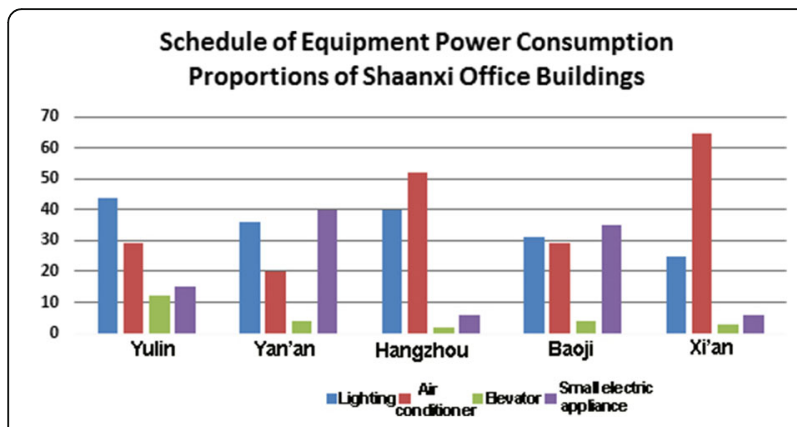

Fig. 2 Schedule of equipment power consumption proportions of Shaanxi office buildings

buildings are classified into high-rise and multi-story categories. The survey finds that the external envelope of these buildings is generally as follows:

Roof: $80-150 \mathrm{~mm}$ pearlite boards are paved on cast-inplace concrete or prefabricated floor slabs, and $200 \mathrm{~mm}$ aerated concrete blocks or $30 \mathrm{~mm}$ XPS boards are adopted with a heat transfer coefficient between 0.65 and $1.0 \mathrm{~W} /\left(\mathrm{m}^{2} \mathrm{~K}\right)$. According to the Design Standard for Energy Efficiency of Public Buildings (GB50189-2015), the thermal performance limit of roofs is $\leq 0.4$ $\mathrm{W} /\left(\mathrm{m}^{2} \mathrm{~K}\right)$ for class A public buildings in a hot-summer cold-winter region and $\leq 0.45 \mathrm{~W} /\left(\mathrm{m}^{2} \mathrm{~K}\right)$ in cold regions. Exterior wall: exterior walls are generally constructed with 370- or 240-mm clay bricks or hollow clay bricks, and a small proportion is built with 200-mm rock-wool sandwich boards, or 25-mm thermal insulation mortar is applied on interior walls of $240-\mathrm{mm}$ hollow clay bricks with a heat transfer coefficient generally between 1.4 and $2.8 \mathrm{~W} /\left(\mathrm{m}^{2} \mathrm{~K}\right)$. According to the standard, the thermal performance limit shall be $\leq 0.6 \mathrm{~W} /\left(\mathrm{m}^{2} \mathrm{~K}\right)$ for class A public buildings in hot-summer cold-winter regions and $\leq 0.5 \mathrm{~W} /\left(\mathrm{m}^{2} \mathrm{~K}\right)$ in cold regions.

Exterior window: aluminum alloy doors and windows are relatively common, and the window to wall ratio is usually between 0.2 and 0.3 . Glass curtain walls largely adopt ordinary single-layer glass with a heat transfer coefficient being generally between 6.4 and $6.6 \mathrm{~W} /\left(\mathrm{m}^{2} \mathrm{~K}\right)$. The standard requires that the thermal performance limit should be $\leq 2.7 \mathrm{~W} /\left(\mathrm{m}^{2} \mathrm{~K}\right)$ in cold regions and $\leq 3.0 \mathrm{~W} /\left(\mathrm{m}^{2} \mathrm{~K}\right)$ in a hot-summer cold-winter region.

The data above reflect the common external envelope performance of existing office buildings found during the survey, which is far from the thermal performance of the external envelope required by the Design Standard for Energy Efficiency of Public Buildings (GB50189-2015) (the standard was implemented in 2005 and revised in 2015) [9]. Meanwhile, the data show that existing office buildings have a great potential for retrofits and will produce considerable economic benefits after energy efficiency retrofit.

\section{Selection of energy efficiency retrofit technology clusters for different climatic regions}

Based on the content presented above, through the establishment of technology clusters, specific energy efficiency retrofits can be carried out by selecting technology clusters corresponding to climatic regions and the retrofit goals for existing public buildings. In this research, the classification of building energy efficiency technologies mainly takes into account:

(1) The practicality of each technology;

(2) More new technologies based on the inclusion of traditional ones;

(3) The systematic nature and completeness of classification as well as the practicality and availability of technologies.

Building energy efficiency technologies are finally classified into four categories, green energy efficiency technologies for building envelopes, renewable energy sources, HVAC equipment systems (including municipal central heating and central air conditioning), and architectural environment control systems, which means achieving the goal of energy efficiency through architectural design, such as natural ventilation, lighting, and sun shading. Taking office buildings, for instance, we can obtain different technology clusters suitable for cold regions and hot-summer cold-winter regions and select appropriate technologies for retrofitting in view of the specific conditions of the existing office buildings (Table 2).

It can be seen from the table that although the buildings are of the same type, the energy efficiency retrofit technologies selected for them are quite different because they are for different climatic regions. For example, in regard to the low-E hollow glass doors and windows, the high transparency type should be selected for the cold region, whereas the sun-shading type should be selected for the hot-summer cold-winter region, whereas in roof retrofitting, impounded and elevated overhead rooves are more suitable for hot-summer cold-winter regions; hot-summer cold-winter regions are not provided with heat in winter. Thus, there is a considerable difference in the energy efficiency technologies for HVAC equipment systems; it is very important to select an energy-efficient air-conditioning system; therefore, technologies such as water-water heat pump systems and air-source heat pump systems can be selected. Overall, there are few differences in the energy-efficient technologies for architectural environmental control systems. 
Table 2 Energy efficiency retrofit technology clusters for existing office buildings (self-reported)

\begin{tabular}{|c|c|c|c|c|}
\hline Technology type & $\begin{array}{l}\text { Green energy efficiency } \\
\text { technologies for building } \\
\text { envelope }\end{array}$ & $\begin{array}{l}\text { Energy efficiency technologies } \\
\text { for renewable energy sources }\end{array}$ & $\begin{array}{l}\text { Energy efficiency technologies } \\
\text { for HVAC equipment system }\end{array}$ & $\begin{array}{l}\text { Energy efficiency technologies } \\
\text { for architectural environment } \\
\text { control system }\end{array}$ \\
\hline 1 & $\begin{array}{l}\text { Internal respiration-type glass } \\
\text { curtain wall (C) }\end{array}$ & Solar wall & Municipal central heating (C) & $\begin{array}{l}\text { Lighting from courtyard and } \\
\text { side-opened space }\end{array}$ \\
\hline 2 & $\begin{array}{l}\text { External respiration-type } \\
\text { glass curtain wall }(\mathrm{HC})\end{array}$ & $\begin{array}{l}\text { Natural ventilation system } \\
\text { of solar chimney }\end{array}$ & Boiler renovation $(C)$ & $\begin{array}{l}\text { Enlarging the area of daylight } \\
\text { opening }\end{array}$ \\
\hline 3 & $\begin{array}{l}\text { External thermal insulation } \\
\text { of exterior wall }\end{array}$ & Solar house & Radiator renovation (C) & $\begin{array}{l}\text { Light-guided sun-shading } \\
\text { system }\end{array}$ \\
\hline 4 & $\begin{array}{l}\text { Internal thermal insulation } \\
\text { of exterior wall }\end{array}$ & Solar PV power generation & $\begin{array}{l}\text { Single-building heat } \\
\text { metering }(C)\end{array}$ & Prism glass window \\
\hline 5 & $\begin{array}{l}\text { Multi-layer hollow glass } \\
\text { door and window }(\mathrm{C}) \\
\text { Hollow glass door and } \\
\text { window }(\mathrm{HC})\end{array}$ & $\begin{array}{l}\text { Heat pump technology for } \\
\text { underground water source }\end{array}$ & $\begin{array}{l}\text { Combined supply system of } \\
\text { cooling, heating, and power }\end{array}$ & Light pipe \\
\hline 6 & $\begin{array}{l}\text { Low-E hollow glass door and } \\
\text { window (high transparency) (C) } \\
\text { Low-E hollow glass door and } \\
\text { window (sun-shading type) (HC) }\end{array}$ & & $\begin{array}{l}\text { Independent VAV heat } \\
\text { pump-type air conditioning } \\
\text { system }\end{array}$ & Reflector \\
\hline 7 & Heat-absorbing glass $(\mathrm{HC})$ & & Radiant cooling ceiling & $\begin{array}{l}\text { Ventilation from courtyard } \\
\text { and side-opened space }\end{array}$ \\
\hline 8 & Adding anteroom (C) & & $\begin{array}{l}\text { Cold-storage air conditioning } \\
\text { system (HC) }\end{array}$ & \\
\hline 9 & $\begin{array}{l}\text { Increasing airtightness of door } \\
\text { and window }\end{array}$ & & $\begin{array}{l}\text { Water-water heat pump } \\
\text { system (HC) }\end{array}$ & Air-guiding wall \\
\hline 10 & $\begin{array}{l}\text { Glass daylighting roof + } \\
\text { sunshade }\end{array}$ & & $\begin{array}{l}\text { Air-source heat pump } \\
\text { system (HC) }\end{array}$ & $\begin{array}{l}\text { Open yard and ventilating } \\
\text { tower }\end{array}$ \\
\hline 11 & Planted roof & & & Night ventilation \\
\hline 12 & Impounded roof $(\mathrm{HC})$ & & & $\begin{array}{l}\text { Air conditioner ventilation + } \\
\text { natural ventilation }\end{array}$ \\
\hline 13 & Elevated overhead roof (HC) & & & $\begin{array}{l}\text { Air supply from air conditioner } \\
+ \text { mechanical ventilation }+ \\
\text { natural ventilation }\end{array}$ \\
\hline 14 & Cold roof system $(\mathrm{HC})$ & & & Efficient light source \\
\hline 15 & $\begin{array}{l}\text { Internally/externally insulated } \\
\text { roof }\end{array}$ & & & Energy efficiency lamp \\
\hline 16 & $\begin{array}{l}\text { Internal sun shading louver, } \\
\text { roller blind, and curtain }\end{array}$ & & & Control device \\
\hline 17 & $\begin{array}{l}\text { Horizontal sunshade + vertical } \\
\text { sunshade }\end{array}$ & & & $\begin{array}{l}\text { Intelligent lighting control } \\
\text { system }\end{array}$ \\
\hline 18 & Integrated sunshade & & & \\
\hline 19 & Deciduous tree & & & \\
\hline 20 & Liana & & & \\
\hline
\end{tabular}

(C) means the technology is only suitable for cold region; (HC) means the technology is only suitable for hot-summer and cold-winter region; unmarked means both are applicable for the two regions

\section{Typical models of existing public buildings}

By using DeST (Designer's Simulation Toolkit) simulation software, a dynamic simulation and analysis tool for the whole year for the thermal environment and performance of the equipment of buildings, this study establishes typical models of existing public office buildings. First, this study sets parameters related to thermal performance according to the climatic region and then determines benchmark buildings (1980s) and reference buildings in compliance with the Design Standard for Energy Efficiency of Public Buildings (GB50189-2015). The purpose is to conduct an in-depth analysis of the energy efficiency effects brought about by retrofits with different building energy efficiency technologies for different climatic regions and then determine energy use quotas. 
The research takes a 24-story typical office building as the prototype to establish a model with DeST simulation software, as shown in Fig. 3. This building has a total area of $28,600 \mathrm{~m}^{2}$, a shape coefficient of 0.22 , a window to wall ratio of 0.25 , a total area of the exterior wall of $14,515 \mathrm{~m}^{2}$, a total area of the exterior window of $3600 \mathrm{~m}^{2}$, and a roof area of $1180 \mathrm{~m}^{2}$.

The vast majority of the existing office buildings in Shaanxi has five to six stories, and the air conditioning equipment is all split-type air conditioners; therefore, this work takes a five-story typical office building as the prototype to establish a model in DeST simulation software, as shown in Fig. 4. This building has a total area of $4000 \mathrm{~m}^{2}$, a shape coefficient of 0.22 , a window to wall ratio of 0.28 , a total area of the exterior wall of $2160 \mathrm{~m}^{2}$, a total area of the exterior window of $605 \mathrm{~m}^{2}$, and a roof area of $850 \mathrm{~m}^{2}$ (Table 3).

\section{Results and discussion}

Economic analysis of different technology systems

Taking existing multi-story office buildings as an example (see Fig. 4), the research sets up different technology systems on the basis of the current problems in the typical model. The technologies are primarily selected by comprehensively considering three objectives, i.e., low-carbon energy efficiency, comfort, and demonstration. Three schemes are formulated following the principle of economic efficiency and their costs estimated for construction [10]. The three schemes are not only an integrated scheme, which means that a technology is preferred without considering economic factors, but also a high-cost-performance scheme, on the one side, which means it considers both the advanced technology and the economic factors, and an economic scheme, on the other, which means that economic factors are prioritized (Table 4).

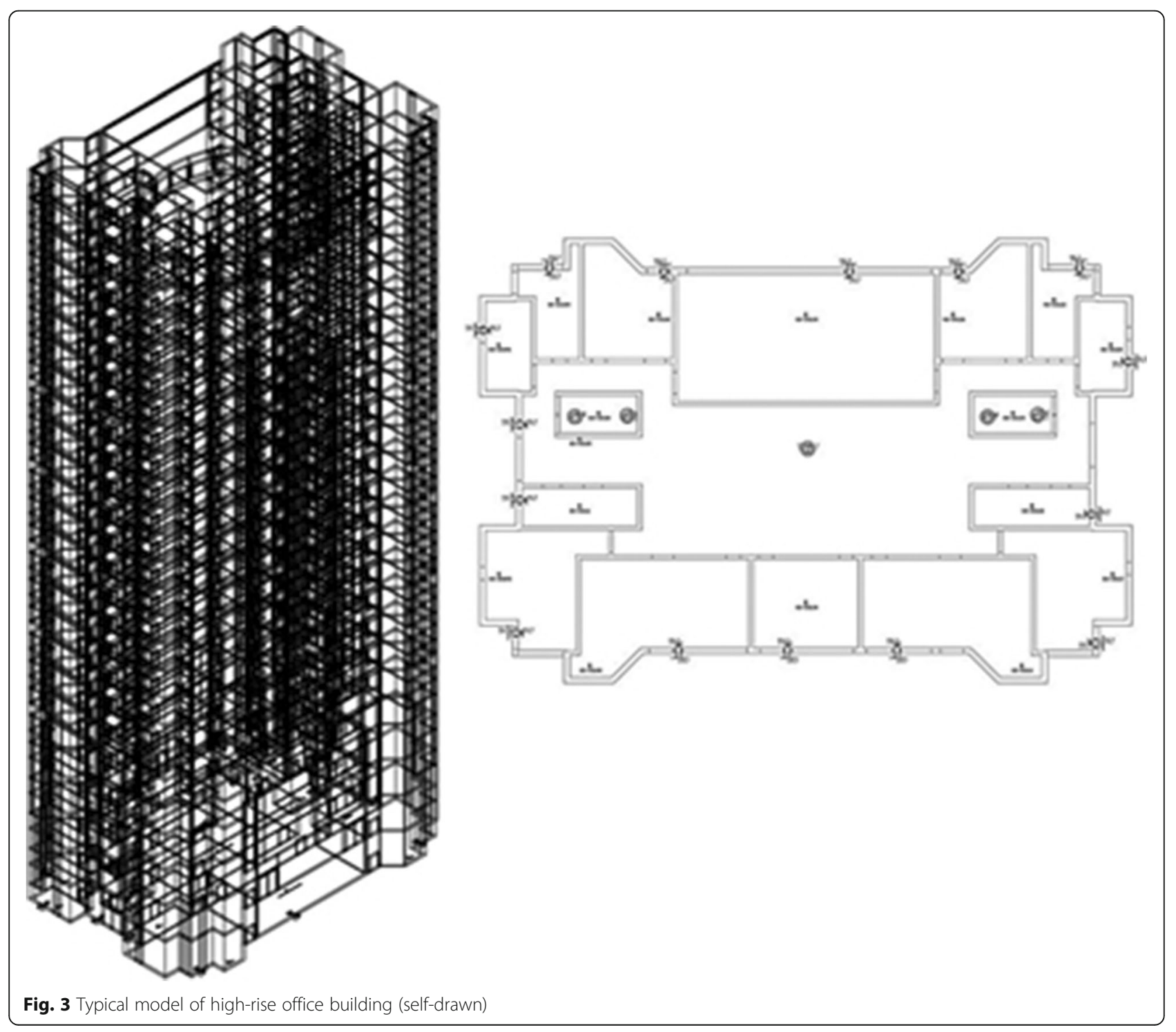




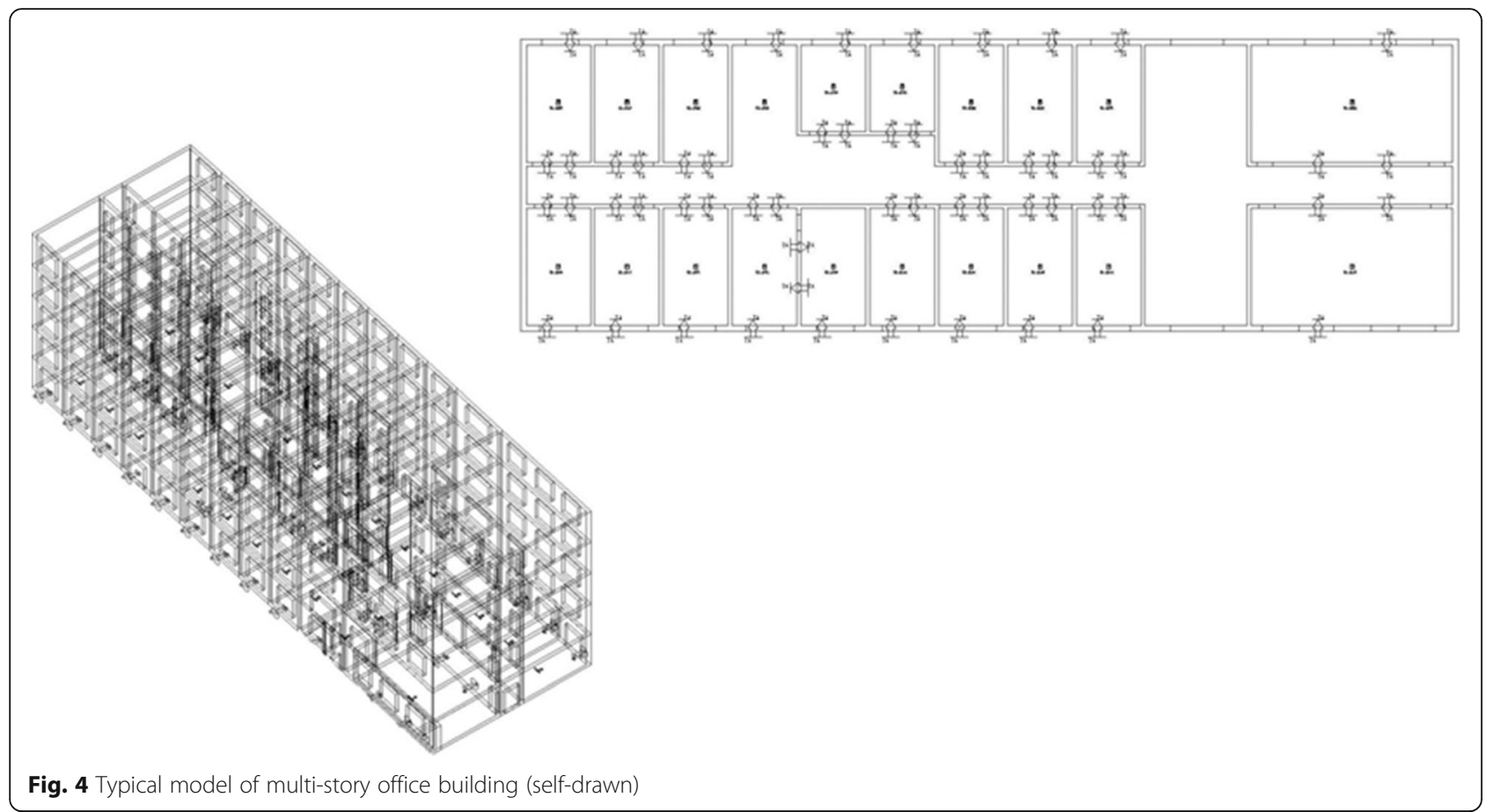

The table shows that the economical scheme adopts more appropriate technologies and achieves energy efficiency by transforming the external building envelope and construction [11], while the integrated scheme proposes an overall retrofit to the external building envelope, including such effective measures as increasing draft staircases and heat recovery caps, optimizing the cooling system, and realizing modularization retrofits.
The cost includes space transformation, material, and equipment investment.

In view of the current development of energy saving and retrofits in China, economic schemes are mostly adopted under the restriction of economic conditions and energy efficiency concepts, but the energy saving effect will be affected; at the same time, the advantages of technology are not fully reflected [12].

Table 3 Comparison table of the thermal performance parameters of typical buildings (self-reported)

\begin{tabular}{|c|c|c|}
\hline Item & Benchmark building (1980) & Reference building (meeting the energy efficiency standard) \\
\hline Wall & $U$ value of exterior wall $-1.7 \mathrm{~W} / \mathrm{m}^{2} \mathrm{~K}$ & $\begin{array}{l}U \text { value of exterior wall }-0.5 \mathrm{~W} / \mathrm{m}^{2} \mathrm{~K} \text { (cold region) } \\
U \text { value of exterior wall }-0.6 \mathrm{~W} / \mathrm{m}^{2} \mathrm{~K} \text { (hot-summer } \\
\text { cold-winter region) }\end{array}$ \\
\hline Roof & $U$ value of roof- $-1.26 \mathrm{~W} / \mathrm{m}^{2} \mathrm{~K}$ & $\begin{array}{l}U \text { value of roof- }-0.45 \mathrm{~W} / \mathrm{m}^{2} \mathrm{~K} \text { (cold region) } \\
U \text { value of roof }-0.40 \mathrm{~W} / \mathrm{m}^{2} \mathrm{~K} \text { (hot-summer cold-winter region) }\end{array}$ \\
\hline Window & $U$ value of window- $-6.4 \mathrm{~W} / \mathrm{m}^{2} \mathrm{~K}$ & $\begin{array}{l}U \text { value of window- }-2.7 \mathrm{~W} / \mathrm{m}^{2} \mathrm{~K} \text { (cold region) } \\
U \text { value of window-3.0 W/m } / \mathrm{m}^{2} \mathrm{~K} \text { (hot-summer cold-winter region) }\end{array}$ \\
\hline Air change rate & 1.5 times $/ \mathrm{h}$ & $\begin{array}{l}0.5 \text { times/h (cold region) } \\
1.0 \text { times/h (hot-summer cold-winter region) }\end{array}$ \\
\hline Running time & $8 / 6$ & $8 / 6$ \\
\hline Cooling system & Central air conditioning, EER: COP3.1/EER2.2 & Central air conditioning, EER: COP5.2/EER3.2 \\
\hline Heat source (central heating) & Natural gas boiler, efficiency-0.8 & Natural gas boiler, efficiency-0.9 \\
\hline Pump & Constant volume & Constant volume \\
\hline Heating period & $\begin{array}{l}\text { November } 15 \text { to March } 15 \text { (next year) } \\
\text { (cold region) }\end{array}$ & November 15 to March 15 (next year) (cold region) \\
\hline Cooling period & June 15 to August 31 (cold region) & June 15 to August 31 (cold region) \\
\hline
\end{tabular}

The heating and cooling in hot-summer cold-winter regions aim to meet the standards for thermal comfort, so the settings are in line with the comfortable temperatures in summer and winter prescribed by the specification 
Table 4 Energy efficiency retrofit schemes for multi-story office buildings (self-reported)

\begin{tabular}{|c|c|c|c|}
\hline \multirow[t]{3}{*}{ Problem classification } & \multicolumn{3}{|c|}{ Energy efficiency technologies and measures adopted } \\
\hline & Scheme 1 & Scheme 2 & Scheme 3 \\
\hline & $\begin{array}{l}\text { Energy efficiency technologies adopted } \\
\text { by the integrated scheme }\end{array}$ & $\begin{array}{l}\text { Energy efficiency technologies adopted } \\
\text { by the high-cost-performance scheme }\end{array}$ & $\begin{array}{l}\text { Energy efficiency technologies } \\
\text { adopted by the economical scheme }\end{array}$ \\
\hline \multirow[t]{4}{*}{ Lighting } & Adding a prism light-guiding system & Adding a prism light-guiding system & Adding a prism light-guiding system \\
\hline & $\begin{array}{l}\text { Adding PV panels on the roof to provide } \\
\text { lighting electricity }\end{array}$ & $\begin{array}{l}\text { Adding PV panels on the roof to } \\
\text { provide lighting electricity }\end{array}$ & Increasing energy efficiency lamps \\
\hline & Reflector & Reflector & Reflector \\
\hline & Adding a prism light-guiding system & Adding a prism light-guiding system & Adding a prism light-guiding system \\
\hline \multirow[t]{2}{*}{ Ventilation } & $\begin{array}{l}\text { Increasing draft staircases }+ \text { heat } \\
\text { recovery caps }\end{array}$ & $\begin{array}{l}\text { Increasing draft staircases + ordinary } \\
\text { vent caps }\end{array}$ & $\begin{array}{l}\text { Increasing draft staircases + ordinary } \\
\text { vent caps }\end{array}$ \\
\hline & Adding vents in an internal corridor & Adding vents in an internal corridor & $\begin{array}{l}\text { Enlarging the opening area of the } \\
\text { window }\end{array}$ \\
\hline \multirow[t]{5}{*}{ Thermal comfort } & Green roof & Adding inverted roof & Adding inverted roof \\
\hline & $\begin{array}{l}\text { Increasing airtightness of door and } \\
\text { window }\end{array}$ & $\begin{array}{l}\text { Increasing airtightness of door and } \\
\text { window }\end{array}$ & $\begin{array}{l}\text { Increasing airtightness of door and } \\
\text { window }\end{array}$ \\
\hline & Adding anteroom & Adding anteroom & Adding anteroom \\
\hline & $\begin{array}{l}\text { Double-layer vacuum low-E glass }+ \\
\text { bridge-cutoff aluminum alloy frame }\end{array}$ & Double-layer vacuum low-E glass & $\begin{array}{l}\text { Double-layer hollow low-E-coated } \\
\text { glass }\end{array}$ \\
\hline & PV panel sunshade & Push-pull plate sunshade & External grating sunshade \\
\hline \multirow[t]{2}{*}{ System } & $\begin{array}{l}\text { Optimizing cooling system and } \\
\text { realizing modularization retrofit }\end{array}$ & $\begin{array}{l}\text { Optimizing cooling system and } \\
\text { realizing modularization retrofit }\end{array}$ & $\begin{array}{l}\text { Adopting efficient pipe network } \\
\text { equipment }\end{array}$ \\
\hline & Replacing or repairing fan coil & Replacing or repairing fan coil & Increasing energy efficiency lamps \\
\hline $\begin{array}{l}\text { Percentage of reducing } \\
\text { the load }\end{array}$ & $\geq 67.11 \%$ & $\geq 51.3 \%$ & $\geq 36.25 \%$ \\
\hline $\begin{array}{l}\text { Estimated construction } \\
\text { cost }\end{array}$ & RMB 5 million & RMB 2 million & RMB 0.5 million \\
\hline
\end{tabular}

\section{Comparative analysis of simulated energy consumption results and national energy use quotas}

The current energy strategy of China clearly proposes promoting an energy production and consumption revolution and controlling the total energy consumption. As energy-efficient civil buildings in China have been implemented, the standard systems for promoting building energy efficiency have so far covered various levels from engineering to product, but standards for building energy consumption are still lacking. During the period (2012-2013) when the first author acted as a visiting scholar at the Lawrence Berkeley National Laboratory in the USA, the author was deeply impacted by the importance attached by the state research institute to building energy efficiency of the USA to policy and standards with the aim of controlling energy consumption at the management level. Therefore, establishing energy use quotas for different types of buildings in different regions was proposed when the research was approved and initiated. Furthermore, the national standard, which was published and implemented in December of 2012, can be used by researchers as the basis for local standards.
For the energy consumption of public buildings, the Standard for Energy Consumption of Building (GB/ T51161-2016) gives constraint values according to "non-heating energy consumption of public buildings" and "heating energy consumption of buildings in cold and severe cold regions,", and different climatic regions are specified with their own constraint values and guide values [13]. Office buildings should serve here as an example (Table 5):

As Shaanxi is situated in a cold region, Xi'an is taken as the example for the constraint and guide values with respect to the constraints of the heating energy consumption indexes of buildings, as is illustrated in the table below (Table 6):

By using DeST software to conduct simulations with the typical models given in this research and including the economical energy efficiency scheme for technology clusters proposed in this article, we can obtain the energy use quotas of existing office buildings in different regions of Shaanxi and compare them with the national standard (Table 7).

The table above shows that the energy consumption of existing office buildings in case they are transformed can 
Lu and Ken Energy, Sustainability and Society (2018) 8:24

Page 9 of 11

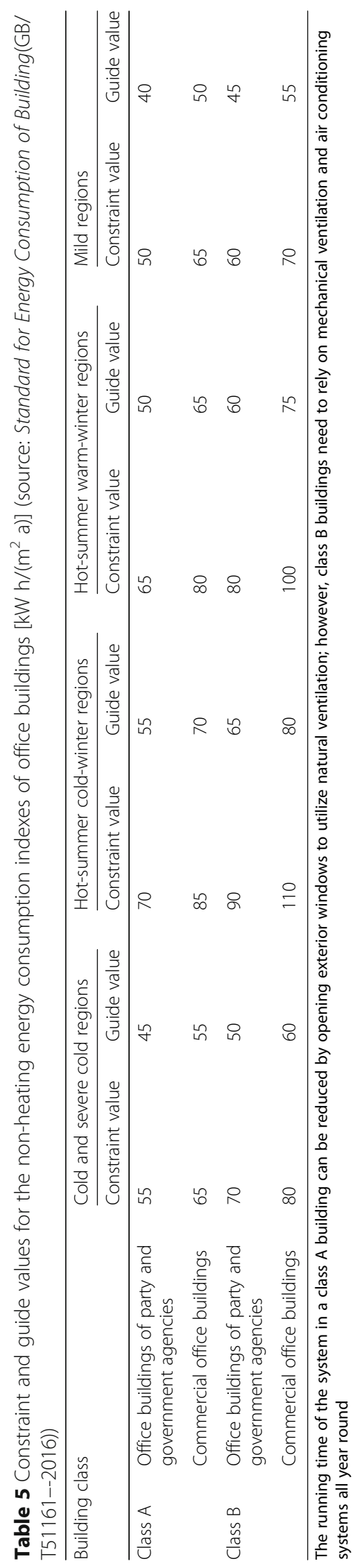


Table 6 Constraint and guide values for the heating energy consumption indexes of buildings (source: Standard for Energy Consumption of Building (GB/T51161-2016))

\begin{tabular}{|c|c|c|c|c|c|c|c|}
\hline \multirow[t]{3}{*}{ Province } & \multirow[t]{3}{*}{ City } & \multicolumn{6}{|c|}{ Heating energy consumption index of building $\left[\mathrm{Nm}^{3} /\left(\mathrm{m}^{2} \mathrm{a}\right)\right]$} \\
\hline & & \multicolumn{3}{|l|}{ Constraint value } & \multicolumn{3}{|l|}{ Guide value } \\
\hline & & $\begin{array}{l}\text { Regional central } \\
\text { heating }\end{array}$ & $\begin{array}{l}\text { Residential quarter } \\
\text { central heating }\end{array}$ & $\begin{array}{l}\text { Single-building } \\
\text { household heating }\end{array}$ & $\begin{array}{l}\text { Regional central } \\
\text { heating }\end{array}$ & $\begin{array}{l}\text { Residential quarter } \\
\text { central heating }\end{array}$ & $\begin{array}{l}\text { Single-building } \\
\text { household heating }\end{array}$ \\
\hline Shaanxi & Xi'an (natural gas) & 7.4 & 8.2 & 7.1 & 3.1 & 4.2 & 3.8 \\
\hline Shaanxi & Xi'an (coal) & 6.3 & 11.1 & / & 3.0 & 5.6 & / \\
\hline
\end{tabular}

basically reach the constraint values specified by the national standard, but there is still a gap between these values and the guide values. This result is related to the selected technology group and economy and can be corrected in practical applications.

\section{Conclusions}

Based on the above research, we can reach the following main conclusions:

(1) It is necessary to set up technology cluster systems for energy-efficient retrofits that are suitable for different climatic regions. The focus of energy efficiency technologies varies with climatic region, and the technologies selected are also different [14]. This research effectively classifies energy efficiency technologies for office buildings in combination with climatic regions and provides a systematic and complete list of technologies.

(2) Different types of public buildings have their own characteristics of energy use. Public buildings are classified into 12 types, including office buildings, commercial buildings, scientific research buildings, and medical buildings. Each type of buildings has its own law of energy consumption; meanwhile, public buildings have a high energy consumption index and a great energy efficiency potential. Taking office buildings as the research object, this study establishes high-rise and multi-story "typical building" models to further study the influences of different climatic regions on the energy consumption and the shape and spatial features of buildings as well as the influence of different building shapes and spaces on the energy consumption of buildings in addition to the influence of equipment's energy efficiency on energy efficiency in the same climatic region.

(3) Local energy use quotas should be formulated for existing public buildings, and energy efficiency management should be promoted for public buildings. The operation management and retrofitting of public buildings to achieve energy efficiency can be realized mainly through two systems, namely, an energy use quota system for public buildings (to determine the energy consumption of public buildings) and the energy audit system for public buildings (to supervise the energy consumption of public buildings). Due to the diversity of public building types and the existence of different climatic regions in Shaanxi, the determination of specific energy use quotas is a top priority and can provide a basis for subsequent retrofits. On the basis of the survey, as well as the testing and simulation analysis, this work aims to assist the administrative department in charge of construction in determining the energy use quotas of different (four) types of public buildings in different regions, to push the development of local building energy efficiency in a more refined direction, and to provide a basis for the formulation of local policies and incentives for energy efficiency.

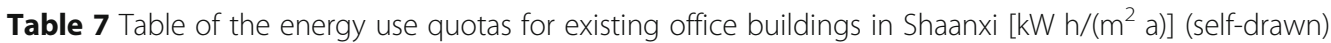

\begin{tabular}{|c|c|c|c|}
\hline Building description & Yulin (cold region A) & Xi'an (cold region B) & $\begin{array}{l}\text { Hanzhong (hot-summer } \\
\text { cold-winter region) }\end{array}$ \\
\hline Office buildings (class A/multi-story) & 116 & 102 & 82 \\
\hline National standard & $\begin{array}{l}\text { 102/70.5 (with heating } \\
\text { energy consumption) }\end{array}$ & & $85 / 70$ \\
\hline Office buildings (class B/high-rise) & 115 & 108 & 102 \\
\hline National standard & $\begin{array}{l}\text { 117/75.5 (with heating } \\
\text { energy consumption) }\end{array}$ & & $110 / 80$ \\
\hline
\end{tabular}

"I" represents a constraint value/a guide value 


\section{Abbreviations}

DeST: Designer's Simulation Toolkit; MOHURD: Ministry of Housing and Urban-Rural Development of China

\section{Funding}

The authors are grateful for the funding support provided by the Shaanxi Social development of the technology research project (2015SF264): "Shaanxi existing public buildings energy efficiency technology clusters and energy management research."

\section{Authors' contributions}

All authors made the same contributions to the article. Both authors read and approved the final manuscript.

\section{Ethics approval and consent to participate}

Not applicable

\section{Consent for publication}

All the authors agree to publish the article.

\section{Competing interests}

The authors declare that they have no competing interests.

\section{Publisher's Note}

Springer Nature remains neutral with regard to jurisdictional claims in published maps and institutional affiliations.

Received: 5 December 2017 Accepted: 22 June 2018

Published online: 01 August 2018

\section{References}

1. The Promotion Center for Science and Technology Development (MOHURD) (2016) Report on the Development of Building Energy Efficiency in China 2016[M]. China Architecture and Building Press, Beijing

2. MOHURD (2017) "The 13th Five-Year" Building energy saving and green building development plan [EB]. http://www.mohurd.gov.cn/wjfb/201703/ t20170314 230978.html.

3. McNeil MA, Wei F, Nan Z (2016) Energy efficiency outlook in China's urban buildings sector through 2030[J]. Energy Policy 97:532-539.

4. Zhai J, LeClaire N, Bendewald M (2011) Deep energy retrofit of commercial buildings: a key pathway toward low-carbon cities[]]. Carbon Manage 2(4):425.

5. Zhang YR, Wang YF (2013) Barriers' and policies' analysis of China's building energy efficiency[J]. Energy Policy 62:768-773.

6. The Promotion Center for Science and Technology Development (MOHURD) (2014) Report on the Development of Building Energy efficiency in China 2014[M]. China Architecture and Building Press, Beijing

7. Xijing S (2008) Energy consumption analysis of governmental office buildings and large scale public buildings in Shaanxi province[J]. Constr Sci Technol 24:74-75.

8. Hong TZ (2009) A close look at the China design standard for energy efficiency of public buildings[]]. Energ Buildings 41:426-435.

9. MOHURD, Design standard for energy efficiency of public buildings (GB50189-2015) [S], 2015.

10. Liu YM, Guo X, Hu FL (2014) Cost-benefit analysis on green building energy efficiency technology application: a case in China[J]. Energy Buildings 82:37-46.

11. Zhou SY, Zhao J (2013) Optimum combinations of building envelop energy efficiency technologies for office buildings in different climatic regions of China[]]. Energy Buildings 57:103-109.

12. Qibo L, Ruogi Z (2013) Research of energy efficiency technology system of university existing building in cold climate zone[J]. Industrial Construction 43:49-53.

13. MOHURD (2016) Standard for energy consumption of building (GB/ T51161-2016) [S].

14. Qibo L, Wei F (2015) Research on the efficiency and economic impact of energy-saving transformation of residential buildings in different climatic regions of China []]. Adv Mater Sci Eng 2015: Article ID 634904. http://dx doi.org/10.1155/2015/634904.

\section{Submit your manuscript to a SpringerOpen ${ }^{\circ}$ journal and benefit from:}

- Convenient online submission

- Rigorous peer review

- Open access: articles freely available online

- High visibility within the field

- Retaining the copyright to your article 